\title{
An update on direct immunofluorescence for diagnosing dermatitis herpetiformis
}

\author{
Marian Dmochowski ${ }^{1}$, Justyna Gornowicz-Porowska ${ }^{1,2}$, Monika Bowszyc-Dmochowska ${ }^{3}$
}

\begin{abstract}
${ }^{1}$ Autoimmune Blistering Dermatoses Section, Department of Dermatology, Poznan University of Medical Sciences, Poznan, Poland 2Department of Medicinal and Cosmetic Natural Products, Poznan University of Medical Sciences, Poznan, Poland ${ }^{3}$ Cutaneous Histopathology and Immunopathology Section, Department of Dermatology, Poznan University of Medical Sciences, Poznan, Poland
\end{abstract}

Adv Dermatol Allergol 2019; XXXVI (6): 655-658

DOI: https://doi.org/10.5114/ada.2019.91415

\begin{abstract}
This mini-review presents an update on the direct immunofluorescence (DIF) for diagnosing dermatitis herpetiformis. The DIF of uninvolved, perilesional skin is a crucial laboratory procedure in diagnosing dermatitis herpetiformis (DH). IgA deposits at the dermal-epidermal junction (DEJ) of perilesional skin with DIF can also be found in coeliac patients with inflammatory skin diseases different from $\mathrm{DH}$. In certain patients presenting with the rash resembling $\mathrm{DH}$, the deposition of exclusively C3 at DEJ can be found. The term "granular C3 dermatosis" was proposed to name such a rash. Recent data on $\mathrm{DH}$ suggest that perhaps the very concept of DH that we are universally accepting now is misleading and should be revised.
\end{abstract}

Key words: dermatitis herpetiformis, direct immunofluorescence, diagnosis.

\section{Direct immunofluorescence: past}

$\mathrm{RH}$ Cormane was the first to report, in an article based on a work presented at the First Congress of the European Society of Pathology, Warsaw, Poland, 1-3 June, 1966, detecting granular immunoglobulin deposits at the dermal-epidermal junction (DEJ) using direct immunofluorescence (DIF) of uninvolved dermatitis herpetiformis (DH) skin [1]. Later, JB van der Meer, a mentee of Cormane, reported that he was able to find granular IgA deposits in uninvolved DH skin with DIF [2]. It was even reported that IgA deposits with DIF can be found in oral mucosa in a fraction of $\mathrm{DH}$ patients showing cutaneous involvement with no gingival lesions [3] hinting that IgA deposition at uninvolved sites distant from lesions may be an epiphenomenon.

\section{Direct immunofluorescence: present and future}

The cost-effective DIF should still be regarded as a crucial procedure in diagnosing $\mathrm{DH}$ at the laboratory level, i.e. it is necessary to perform it in any individual suspected to have DH. Perilesional, uninvolved skin, similarly to other autoimmune blistering dermatoses showing cutaneous lesions, is the optimal biopsy site for DIF [4] as this approach minimizes the risk of obtaining a false negative result reducing the need for the biopsy repetition. The tissue for DIF should be processed according to the established methodology; it is vital not to use formalin fixation and paraffin embedding.

DIF can be visualized with short arc mercury lamp-operated microscopy, blue light-emitting diode technologyoperated microscopy and laser scanning confocal microscopy [5] (Figure 1). Conceptually, a super/high resolution microscopy technique known under the acronym STED (stimulated emission depletion) [6], if adapted for the routine laboratory use, should also be useful for evaluation DIF images, especially as nowadays it can be fixed to the microscope of any type utilizing just the shoebox size equipment.

With DIF the following three main patterns of IgA deposition can be seen, namely microgranular deposits at the tips of the dermal papillae, microgranular-fibrillar or just fibrillar deposits at the tips of the dermal papillae and microgranular deposits along the DEJ [7-9]. However, with serial sectioning of the tissue as many as seven patterns can be seen since grouping (Figure 1) of three main patterns is possible (in mathematics this is the

Address for correspondence: Prof. Marian Dmochowski MD, PhD, Autoimmune Blistering Dermatoses Section, Department of Dermatology, Poznan University of Medical Sciences, 49 Przybyszewski St, 60-355 Poznan, Poland, e-mail: mkdmoch@wp.pl

Received: 11.04.2019, accepted: 30.07.2019. 
concept of the power set but excluding the empty set) [7]. Japanese authors have recently dubbed the variety of DH with a fibrillar pattern in an apt way as fibrillartype DH showing that those deposits are co-localizing with fibrinogen which is in agreement with non-fibrillar types of DH and can have pathological importance as epidermal transglutaminase tends to be translocated from its physiological expression sites and also deposited at sites of IgA deposition [10, 11]. In an earlier study, onethird of Japanese DH patients showed fibrillar IgA deposition [12]. This should be regarded as an unusually high frequency since that pattern was detected in merely $9 \%$ (5 of 54) of Polish DH patients [13]. Initially, there were data that in all $8 \mathrm{DH}$ cases studied both IgA1 and IgA2 were forming IgA cutaneous deposits seen with DIF, although IgA1 predominated in them [14]. Later, we detected IgA1 (found in all $24 \mathrm{DH}$ cases) and IgA2 (found in 4 of 13 DH cases) cutaneous deposits with DIF concluding
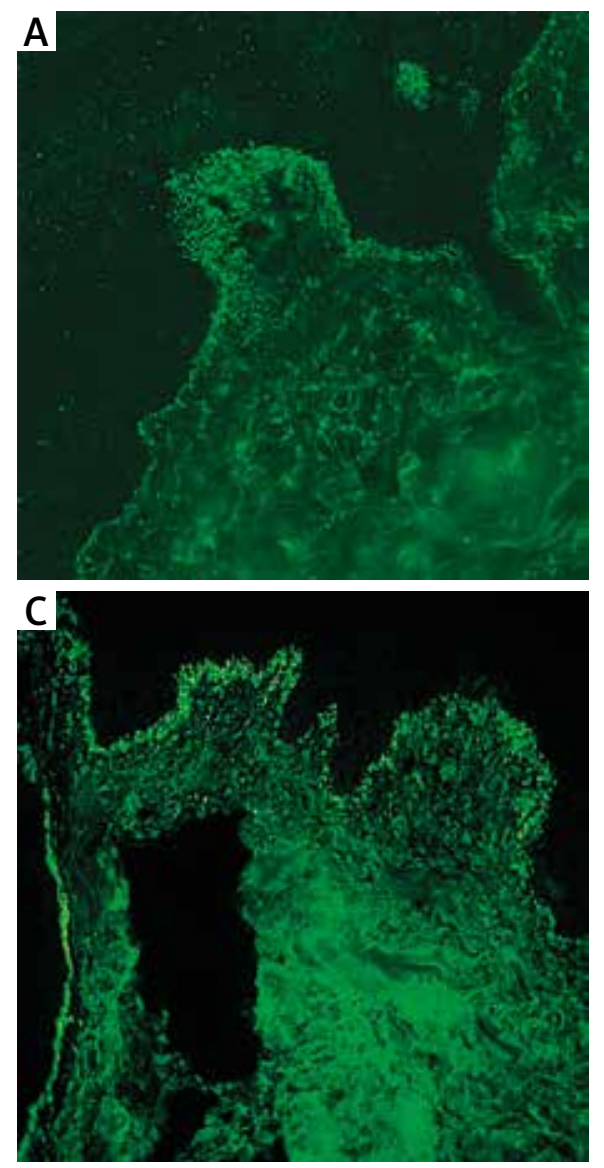

that IgA1 deposition was far more frequent and intense compared to that of IgA2 [13]. What may be important from the diagnostic point of view, in certain of our $\mathrm{DH}$ cases testing for IgA1 gave less background staining compared to IgA making the interpretation of imaging results easier. It was reported that IgA deposits can disappear from the papillary dermis of patients with $\mathrm{DH}$ after a long-term gluten-free diet [15].

In addition to IgA deposition in the close vicinity of the DEJ, IgA was reported in certain patients with $\mathrm{DH}$ to be present in the vessels of the papillary dermis and in the subpapillary vasculature [16] of the reticular dermis. Even less frequently, IgA is detectable in the elastic fibers, in the arrector pili muscles, in the fibers around hair follicles and in the basement membrane of sweat glands and ducts [17]. Microgranular IgA deposits can occasionally be detected along the basement membrane of the hair follicles (Figure 1). The value of such findings for di-
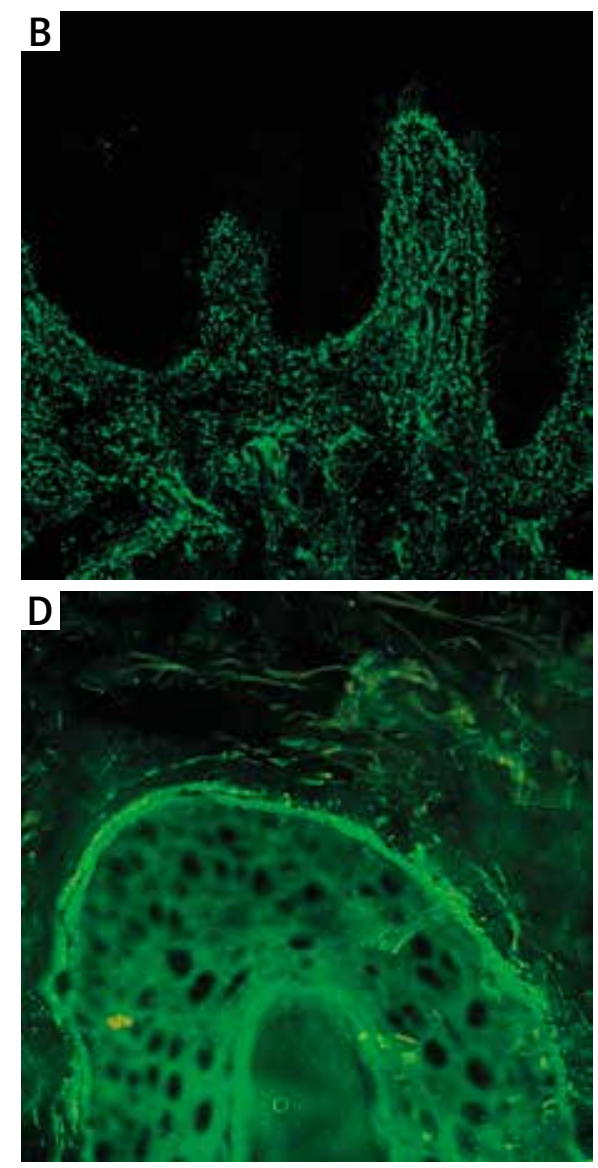

Figure 1. Microgranular IgA deposits at the tips of the dermal papillae in a young female with DH in DIF of perilesional skin visualized with blue light-emitting diode technology-operated microscopy (A). Microgranular IgA deposits at the tips of the dermal papillae in a young female with DH in DIF of perilesional skin visualized with laser scanning confocal microscopy (B). Simultaneous, in a single section, microgranular lgA deposits at the tips of the dermal papillae, microgranular-fibrillar deposits at the tips of the dermal papillae and microgranular deposits along the DEJ in a young male with DH in DIF of perilesional skin visualized with short arc mercury lamp-operated microscopy (C). Microgranular IgA deposits along the basement membrane of a hair follicle in a young male with DH in DIF of perilesional skin visualized with short arc mercury lamp-operated microscopy (D) (original objective magnifications 40x) 
agnosing DH is uncertain; they may simply reflect either the physiologically dynamic expression of $\mathrm{DH}$ antigens (epidermal and tissue transglutaminases) in the tissue or the traffic of those antigens through various structures of the skin affected by DH pathology or both. Interestingly in this respect, codistribution of tissue transglutaminase and tissue-bound IgA in jejunum of patients with $\mathrm{DH}$ was reported in the meeting abstract [18].

IgA deposits at the DEJ of perilesional skin with DIF can also be found in coeliac patients with inflammatory skin diseases different from $\mathrm{DH}$ and, therefore, could even be considered as a marker of coeliac disease [19]. Interestingly, analysing $16 \mathrm{DH}$ patients with both ELISA and immunoblot, we noticed certain discrepancies between the results of DIF and testing for circulating autoantibodies incriminated to be $\mathrm{DH}$ serum biomarkers. Specifically, according to the interpretation of Cohen's $\kappa$, the inter-rater agreement/reliability between DIF and ELISA as well as immunoblot detecting antibodies to tissue transglutaminase and nonapeptides of gliadin was weak [20]. There are some DH patients described in the literature with negative DIF [21]. Probably, as suggested by Sousa et al., technical errors, failure of current laboratory methods in detecting cutaneous IgA deposits in some patients, and focal deposition of IgA in the skin may explain the negative DIF in DH. Furthermore, it was reported that there are female DH sufferers having the positive DIF in whom hypersensitivity to nickel detected with epicutaneous patch tests with 5\% nickel sulfate hexahydrate in Vaseline can be found [22]. Putting aside the issue whether in certain females $\mathrm{DH}$ is pathologically related to nickel hypersensitivity, this coincidence definitely widens the burden of skin problems in such individuals [23]. Thus, expanding on initial ideas of Beutner et al. [24], thoughtful consideration of all clinical as well as imaging and molecular-biochemical laboratory data available is mandatory to establish the diagnosis of $\mathrm{DH}$.

With DIF techniques, $\mathrm{DH}$ bodies detectable in the papillary dermis of affected DH skin were found to be comprised of an amalgamation of IgA, IgM as well as armadillo repeat gene deleted in velo-cardio-facial syndrome (ARVCF), desmoplakins 1 and 2, and plakophilin 4, but not tissue/epidermal transglutaminase [24]. Pathophysiologic significance of DH bodies is at present virtually unknown, but they may be a sign of an ongoing tissue repair processes. The diagnostic potential of $\mathrm{DH}$ bodies remains to be elucidated.

It was reported that in some patients with the rash resembling DH the deposition of exclusively C3 at DEJ was found. These patients may represent a new disease entity, different from $\mathrm{DH}$ and plausibly related to the noncoeliac gluten sensitivity [25], but important as far as the laboratory differentiation of DH with imaging DIF is concerned, for which the term "granular C3 dermatosis" was proposed [26]. It should be stressed here that coining catchy terms for apparently newly described dermatoses should be done extremely cautiously as the term "psoriasis bullosa acquisita" [27] was discarded quickly after an initial enthusiasm.

\section{Acknowledgments}

We are grateful to Professor Miklós Sárdy, Budapest, Hungary, the coordinator of the EADV dermatitis herpetiformis guideline project, for inspiring us to prepare this minireview based on issues formulated as part of this project. This work was also undertaken in conjunction with activities of the European Reference Network-Skin.

\section{Conflict of interest}

The authors declare no conflict of interest.

\section{References}

1. Cormane RH. Immunofluorescent studies of the skin in lupus erythematosus and other diseases. Pathol Eur 1967; 2: 170-80.

2. van der Meer JB. Granular deposits of immunoglobulins in the skin of patients with dermatitis herpetiformis. An immunofluorescent study. Br J Dermatol 1969; 81: 493-503.

3. Nisengard RJ, Chorzelski T, Maciejowska E, Kryst L. Dermatitis herpetiformis: IgA deposits in gingiva, buccal mucosa, and skin. Oral Surg Oral Med Oral Pathol 1982; 54: 22-5.

4. Zone JJ, Meyer LJ, Petersen MJ. Deposition of granular IgA relative to clinical lesions in dermatitis herpetiformis. Arch Dermatol 1996; 132: 912-8.

5. Gornowicz-Porowska J, Bowszyc-Dmochowska M, RaptisBolwach $\mathrm{M}$, et al. Blue light-emitting diode technology-operated microscopy is preferable to both short arc mercury lamp-operated microscopy and laser scanning confocal microscopy for direct immunofluorescence images evaluation in routinely diagnosing subepidermal autoimmune blistering diseases. Microsc Res Tech 2019; 82: 1735-40.

6. Schermelleh L, Heintzmann R, Leonhardt H. A guide to super-resolution fluorescence microscopy. J Cell Biol 2010; 190: 165-75.

7. Dmochowski M, Bowszyc-Dmochowska M, DańczakPazdrowska A. On patterns of IgA deposits in the skin of patients with dermatitis herpetiformis. Adv Dermatol Allergol 2003; 20: 46-8.

8. Ko CJ, Colegio OR, Moss JE, McNiff JM. Fibrillar IgA deposition in dermatitis herpetiformis-an underreported pattern with potential clinical significance. J Cutan Pathol 2010; 37: 475-7.

9. Lilo MT, Yan S, Chapman MS, Linos K. A case of dermatitis herpetiformis with fibrillar immunoglobulin A deposition: a rare pattern not to be missed. Am J Dermatopathol 2019; 41: 511-3.

10. Makino T, Shimizu T. Fibrillar-type dermatitis herpetiformis. Eur J Dermatol 2019; 29: 115-20.

11. Bowszyc-Dmochowska M, Dmochowski M. Transglutaminaza naskórkowa umiejscawia się w skórze właściwej poniżej połączenia skórno-naskórkowego u jedynie mniejszości chorych na opryszczkowate zapalenie skóry. Dermatol Klin 2006; 8: 141-2.

12. Ohata C, Ishii N, Hamada T, et al. Distinct characteristics in Japanese dermatitis herpetiformis: a review of all 91 Japanese patients over the last 35 years. Clin Dev Immunol 2012; 2012: 562168. 
13. Wolnik-Trzeciak G. Autoimmunizacja wobec naskórkowej i tkankowej transglutaminazy w odniesieniu do wybranych czynników skórnej patogenezy opryszczkowatego zapalenia skóry. PhD thesis. Poznań 2005, 1-114.

14. Wojnarowska F, Delacroix D, Gengoux P. Cutaneous IgA subclasses in dermatitis herpetiformis and linear IgA disease. J Cutan Pathol 1988; 15: 272-5.

15. Hietikko M, Hervonen K, Salmi T, et al. Disappearance of epidermal transglutaminase and IgA deposits from the papillary dermis of patients with dermatitis herpetiformis after a long-term gluten-free diet. Br J Dermatol 2018; 178: e198-201.

16. Preisz K, Sárdy M, Horváth A, Kárpáti S. Immunoglobulin, complement and epidermal transglutaminase deposition in the cutaneous vessels in dermatitis herpetiformis. J Eur Acad Dermatol Venereol 2005; 19: 74-9.

17. Barnadas MA. Dermatitis herpetiformis: a review of direct immunofluorescence findings. Am J Dermatopathol 2016; 38: 283-8.

18. Preisz K, Kárpáti S, Sárdy M, et al. Codistribution of tissue transglutaminase and tissue-bound IgA in jejunum of patients with dermatitis herpetiformis. J Invest Dermatol 2000; 115: 580.

19. Bonciolini V, Antiga E, Bianchi B, et al. Granular IgA deposits in the skin of patients with coeliac disease: is it always dermatitis herpetiformis? Acta Derm Venereol 2019; 99: 78-83.

20. Gornowicz-Porowska J, Jałowska M, Seraszek-Jaros A, et al. Ocena przydatności nowo opracowanego, wieloparametrycznego testu immunoblot do rutynowej serodiagnostyki opryszczkowatego zapalenia skóry. Dermatol Rev 2019; 106 Suppl. 1: 54.

21. Sousa L, Bajanca R, Cabral J, Fiadeiro T. Dermatitis herpetiformis: should direct immunofluorescence be the only diagnostic criterion? Pediatr Dermatol 2002; 19: 336-9.

22. Dmochowski M, Bowszyc-Dmochowska M. Nadwrażliwość na nikiel a opryszczkowate zapalenie skóry. Dermatol Klin 2007; 9: 275-6.

23. Beutner EH, Baughman RD, Austin BM, et al. A case of dermatitis herpetiformis with IgA endomysial antibodies but negative direct immunofluorescent findings. I Am Acad Dermatol 2000; 43: 329-32.

24. Abreu Velez AM, Yi H, Griffin Girard J, et al. Dermatitis herpetiformis bodies and autoantibodies to noncutaneous organs and mitochondria in dermatitis herpetiformis. Our Dermatol Online 2012; 3: 283-91.

25. Bonciolini V, Bianchi B, Del Bianco E, et al. Cutaneous manifestations of non-celiac gluten sensitivity: clinical histological and immunopathological features. Nutrients 2015; 7: 7798-805.

26. Hashimoto T, Tsuruta D, Yasukochi A, et al. Granular C3 dermatosis. Acta Derm Venereol 2016; 96: 748-53.

27. Morris SD, Mallipeddi R, Oyama N, et al. Psoriasis bullosa acquisita. Clin Exp Dermatol 2002; 27: 665-9. 